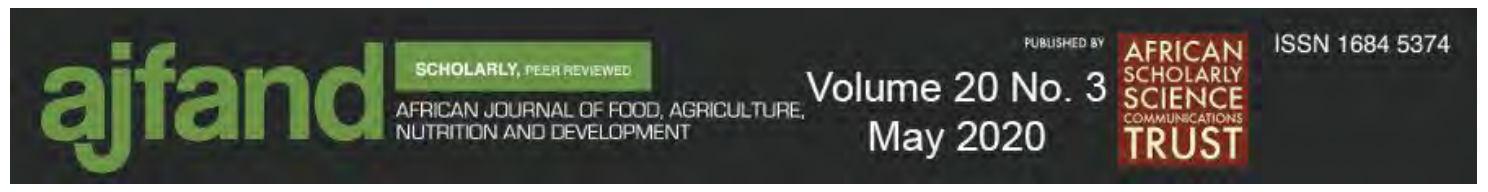

\title{
MORPHOLOGICAL CHARACTERISTICS AND DISTRIBUTION OFCOLLETOTRICHUM ISOLATES MORPHOTYPES INFECTING MANGO (MANGIFERA INDICA L.) IN THE NORTH OF CÔTE D'IVOIRE
}

\author{
Dembélé DD ${ }^{1,2 *}$, Kamara $A^{1}$, Grechi $\mathbf{I}^{3,4}$, Silué $\mathbf{N}^{1}$, \\ $\mathrm{N}^{\prime}$ goran NS${ }^{1}$, Yéo YS ${ }^{1}$, Rey J-Y ${ }^{4,5}$ and D Koné ${ }^{1,2}$
}

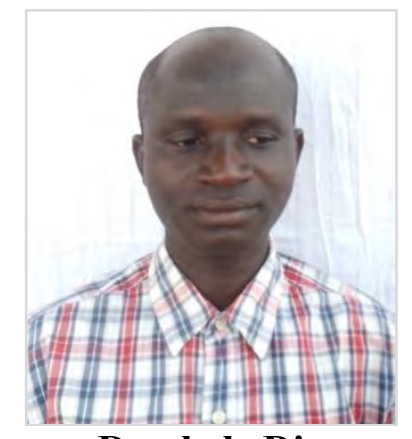

Dembele Dio

*Corresponding author email: dembeledio@yahoo.fr

${ }^{1}$ Laboratory of Plant Physiology, UFR Biosciences, University Félix HOUPHOUËTBOIGNY, Cocody, 22 B.P 582 Abidjan 22, Côte d'Ivoire

${ }^{2}$ African Center of Excellence in Climate Change, Biodiversity and Sustainable Agriculture, University Félix HOUPHOUËT-BOIGNY, Cocody, 22 B.P. 582 Abidjan 22, Côte d'Ivoire

${ }^{3}$ CIRAD, UPR HortSys, F-97455 Saint-Pierre, Réunion, France

${ }^{4}$ CIRAD, UPR HortSys, F-34398 Montpellier, Réunion, France

${ }^{5}$ HortSys, Université Montpellier, CIRAD, Montpellier, France 


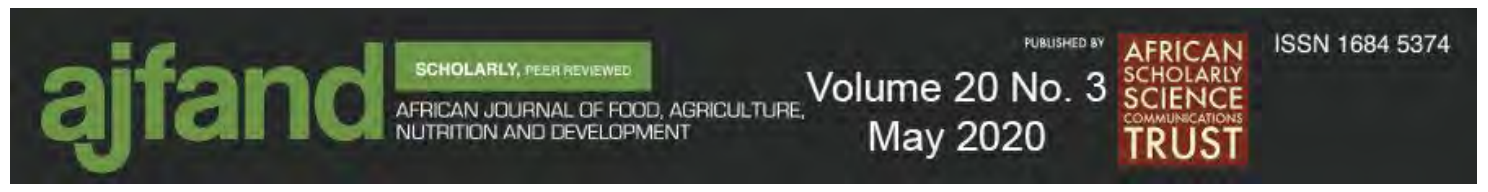

\begin{abstract}
Anthracnose caused by Colletotrichum species is the most important field and postharvest disease infecting mango worldwide. A survey was conducted in the seven mango producing districts in the north of Côte d'Ivoire to identify and characterize Colletotrichum species isolates associated with mango leaves necrosis and fruit rots. A total of 70 isolates were identified based on morphological and cultural characters. Most of isolate colour were grey or grey whitish $(36 \%)$, cottony $(71 \%)$ with cylindrical conidia $(97 \%)$ rounded on both ends $(57 \%)$. Three texture types were observed in colonies of the seventy isolates. Most of the isolates were cottony (71\%) followed by abundant aspect $(23 \%)$ and closely appressed $(6 \%)$. According to conidia shape, two species of Colletotrichum; Colletotrichum gloeosporioides (97\%) and C. acutatum (3\%) were identified in the seventy isolates. Conidia length and width varied respectively from 15.4 to $19.7 \mu \mathrm{m}$ and 4.8 to $5.2 \mu \mathrm{m}$. The Average Linear Growth Rate (ALGR) 7 days after culture varied from 0.76 to $0.91 \mathrm{~cm} \mathrm{day}^{-1}$. Multivariate analysis grouped the 70 isolates into four morphotypes containing, respectively: 5 (7\%), 7 (10\%), 17 (24\%) and $41(59 \%)$ isolates. Isolates of morphotype 1 were characterized by whitish obverse and reverse colour with an abundant mycelia aerial aspect. The second morphotypes were represented by isolates with obverse and reverse brownish grey colour and contained both conidia with two rounded ends, and one rounded and one sharped ends. The third morphotype consisted of isolates with obverse and reverse grey whitish colour. The fourth morphotype consisted of isolates with obverse and reverse respectively dark grey and grey or vice versa. Conidial length and width of morphotypes varied, respectively, from 14.5 to $17.2 \mu \mathrm{m}$ and 4.6 to $5.2 \mu \mathrm{m}$. ALGR of morphotypes varied from 0.84 to 0.87 $\mu \mathrm{m}$ day $^{-1}$. The present study highlighted that morphological variation of Colletotrichum species existed among the different isolates and the districts surveyed. However, to overcome the inadequacies of this traditional morphological identification, sequence analyses are needed to be carried out to confirm the identity of these Colletotrichum species isolates.
\end{abstract}

Key words: Mango, Anthracnose, Colletotrichum sp., isolate, Multivariate analysis, Morphotype, Rainy season, Dry season, Preharvest, Postharvest 


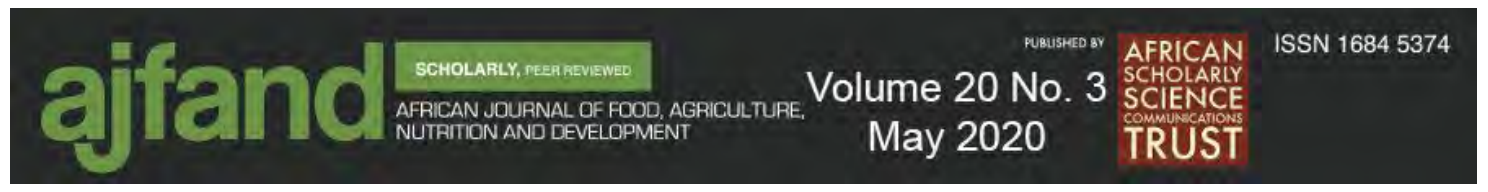

\section{INTRODUCTION}

Anthracnose caused by Colletotrichum species is a major pre and/or post harvest disease which seriously constrain the production, marketing and export of tropical fruits[1,2]. This disease has been reported in many parts of the world where the climate is suitable for mango production to be the most important field and postharvest disease of the crop [3-5]. Its incidence can reach almost $100 \%$ in fruits produced under wet or very humid conditions [6], and yield losses ranging from 30\% - 60\% were recorded due to anthracnose in mango in several countries [7,8]. Anthracnose infects leaves, flowers, juvenile fruit or even twigs, causing leaf necrosis, blossom blight, mummified fruits $[6,8]$ and dieback [9]. The postharvest fruit rots are mainly caused by Colletotrichum gloeosporioides, and to a lesser extent by C. acutatum [10]. However, these two species are complex and accurate information concerning the causal species within these complexes is lacking $[11,12]$. Thus, the taxonomy and nomenclature in this genus is confusing, even to scientists working in the field, and inaccurate diagnosis of species is not uncommon [11].

Among the two species of Colletotrichum infecting mango, C. gloeosporioides, known as one of the world's most important pathogens, is a species complex comprising morphologically indistinguishable but genetically and biologically isolated species $[12,13]$. However, traditional identification and characterization of Colletotrichum species has relied primarily on differences in morphological features such as colony colour, size and shape of conidia and appressoria, mycelial growth rate, presence or absence of setae, and existence of the Glomerella teleomorph [14-16]. Additional criteria to cultural and morphological characteristics used to differentiate Colletotrichum species are specific pathogenicity to a particular host, or host group, and cross-infection [6].

In Côte d'Ivoire, anthracnose is the most important disease limiting mango producing, marketing and export $[17,18]$. In 2010, this disease was reported to cause fruits losses of $24 \%$ and $26 \%$ respectively in Ferkessédougou (Tchologo district) and Odienné (Kabadougou district). The disease has become a menace to both farmers and exporters because it makes mango production no longer attractive in some districts in the north of Côte d'Ivoire. However, little work has been reported on Colletotrichum sp. the causal agent of this disease in many mango producing districts for export. Thus, there is scanty information regarding the different Colletotrichum species responsible for mango anthracnose in these regions. Characteristics of some isolates of Colletotrichum spp. collected from three producing districts (Kabadougou, Poro and Tchologo) and markets surveys in Abidjan in the south of Côte d'Ivoire have been reported [18,19]. Findings demonstrated that $C$. acutatum is not implicated in postharvest losses of mango in Côte d'Ivoire [18]. So, data need to be updated because former studies were limited to only three out of the seven mango producing districts in the north of Côte d'Ivoire. Besides, the characterization of anthracnose causal agent has also paramount importance to develop suitable strategies of its management.

Studies regarding morphological features on Colletotrichum species have not yet been extended to the entire mango producing districts in the north of Côte d'Ivoire. Thus, our 


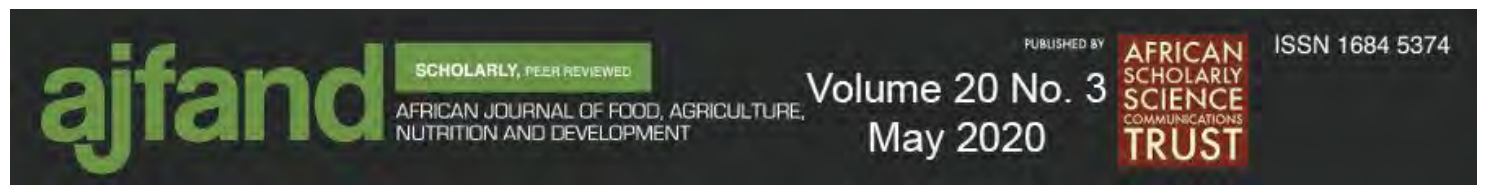

study aimed to characterize the species of Colletotrichum associated with mango leaves necrosis and fruit rots in the seven mango producing districts for export of the country.

\section{MATERIALS AND METHODS}

\section{Field surveys and sampling}

Surveys were conducted during the dry season (January to February) and rainy season (July to August) in 2018 in the seven mango producing districts (Bagoué, Béré, Folon, Hambol, Kabadougou, Poro and Tchologo) located in the north of Côte d'Ivoire. Samples of infected mango leaves were collected in 45 orchards in the above- mentioned districts and taken to the laboratoryfor isolation and characterization of the causal agent. Those of fruits were obtained by collecting green mature fruits in 24 orchards located in five districts (Bagoué, Béré, Folon, Poro and Tchologo). Fruits were stored at room temperature ranged from 26 to $34.5^{\circ} \mathrm{C}$ and relative humidity ranged from 58.5 to $78.5 \%$ for ripening. Fifteen days after incubation diseased fruits were used for Colletotrichum species isolation in the laboratory.

\section{Identification and characterization of the anthracnose causal agent Isolation of the causal agent}

Diseased leaves were collected and green mature fruits collected were stored for fifteen days and Colletotrichum species were isolated. The isolates were characterized morphologically, classified by multivariate analysis in morphotypes and a map of their distribution was established. Isolations were carried out from leaves and fruit showing symptoms of anthracnose to confirm the presence of Colletotrichum species. At the laboratory, the infected mango leaves were cut into small pieces with a sterilized scalpel and soaked in $70 \%$ ethanol solution for $3 \mathrm{~min}$ and in 1\% Sodium hypochlorite $(\mathrm{NaOCl})$ solution for another $3 \mathrm{~min}$ [20]. Then, tissues were rinsed three times in sterilized distilled water [21], dropped on sterile paper towels, and once dried they were plated onto Potato Dextrose Agar (PDA) in Petri dishes [20]. Petri dishes were incubated at room temperature $\left(25-28^{\circ} \mathrm{C}\right)$ after wrapping with Parafilm until the appearance of fungal growth. For fruits, isolations were carried out on those sampled for disease assessment and showing symptoms of anthracnose fifteen days after incubation. Those fruits were washed with soapy water [22] and sterilized following steps described below for leaves. Sterilized fruits were swabbed using a clean sterilized paper towel. Then, two crossed incisions in the form of $\mathrm{V}$ were made at the front of progression of the rotting process with a sterile scalpel. Three pieces of flesh and peel were taken and placed in a Petri dish containing PDA amended with 100 ppm of chloramphenicol [23] and incubated at room temperature. Five days after incubation, isolated colonies were sub-cultured into fresh plates until pure cultures were obtained [20] and were identified.

\section{Identification and classification of Colletotrichum sp. isolates}

Identification and characterization of Colletotrichum isolates were performed using morphological features of a 7-day old culture. They comprised macroscopic and microscopic characters (table 1), as those proposed by [24] for multivariate analysis of some characteristics of South African isolates of Colletotrichum. Macroscopic characters such as aerial aspect of colonies (AAC), colony obverse colour (COC) and colony reverse colour (CRC) were observed visually. Microscopic characters such as conidia shape 


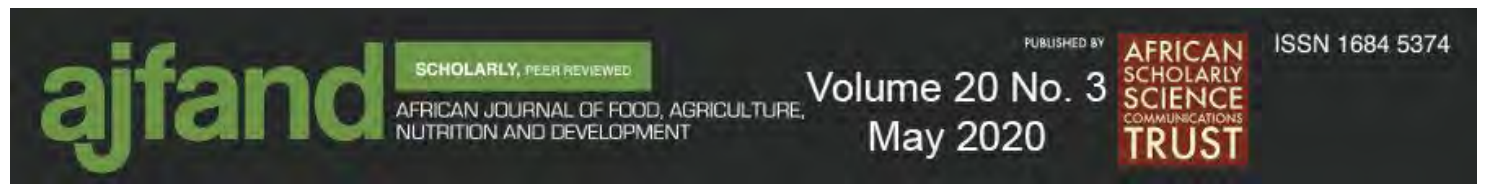

(CS), conidia extremity shape (CE), and conidia length (CL) and width (CW) were obtained by observing a drop of the suspension of each isolate fixed on a slide under compound microscope fitted with an ocular micrometer at 400X magnification. Then, the length $(\mathrm{CL})$ and width $(\mathrm{CW})$ of 30 randomly selected conidia per isolate were measured. The diameter of the mycelia growth of three plates per isolate was measured daily for 7 days with a ruler on the reverse side of the plate along lines ruled across two perpendicular diameters of the Petri plates. Growth rate per isolate was calculated as the 7 -day average of mean daily growth $\left(\mathrm{cm} \mathrm{day}^{-1}\right)$. The Average Linear Growth Rate (ALGR) per isolate was determined according to the following formula [25]:

$\operatorname{ALGR}=\left(\mathrm{C}_{7}-\mathrm{C}_{0}\right) / 7$

Where $\mathrm{C}_{0}$ is the initial colony diameter $\left(\mathrm{C}_{0}=10 \mathrm{~mm}\right)$ and $\mathrm{C} 7$ is the colony diameter on the $7^{\text {th }}$ day.

The eight morphological and cultural characteristics of Colletotrichum spp.isolates (Table 1) were then used for their classification and the identification of morphotypes.

\section{Pathogenicity tests}

The pathogenicity test was performed by using one isolate representing each morphotype obtained after classification of Colletotrichum spp. isolates. The selected isolates were randomly chosen in each morphotype for the test.

\section{Preparation of inoculum}

The suspension of conidia was prepared by suspending mycelia scraped of Colletotrichum spp. from 10 days old culture in $3 \mathrm{~mL}$ sterilized distilled water and shaking vigorously for $3 \mathrm{~min}$ [20]. The spores suspension obtained was observed using a haemacytometer and was adjusted to $1 \times 10^{6}$ spores/millimeter [26].

\section{Inoculation of fruits}

Tests were carried out using green matured mango fruits of Kent variety randomly collected in four orchards in the department of Sinématiali. At laboratory, fruits were washed and disinfected in $70 \%$ ethanol and $1 \% \mathrm{NaOCl}$. The disinfected fruits were then rinsed in four changes of sterilized distilled water and air dried at room temperature before inoculations [20,26]. Inoculations of fruits were done following [27] wounded inoculations procedures. Fruits were pierced with sterilized needle in three portions and then, with pipette $20 \mu \mathrm{L}$ containing $1 \times 10^{6} \mathrm{~mL}^{-1}$ spores suspension for each isolate representing each morphotype was dropped on the three wounded portions of each of the three fruits [28]. Control fruits were inoculated with $20 \mu \mathrm{L}$ of sterile distilled water. Inoculated fruits were incubated at $25-28^{\circ} \mathrm{C}$ in cartons lined with moist laboratory wipes and covered with plastic bags [29] and daily sprayed with sterilized distilled water to maintain at $95 \%$ relative humidity. Five days after incubation, lesions diameters at the inoculation points were measured in two opposite directions [30]. The ninth measures per isolate (3 fruits per isolate and 3 inoculation points per fruit) were used to calculate the mean lesion diameter according to the following formula: 


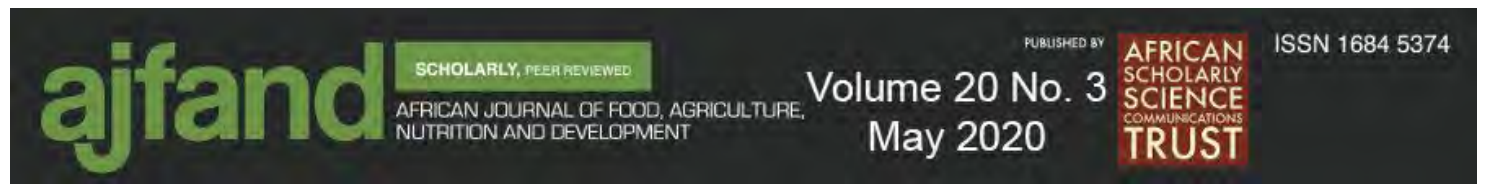

MDL $=\sum_{\mathrm{m}=1}$ à $9\left(\mathrm{~d}_{\mathrm{m}}\right) / 9$, where $\mathrm{d}_{\mathrm{m}}$ is the mean diameter per inoculation point $\left(\mathrm{d}_{\mathrm{m}}=\left(\mathrm{d}_{1}+\mathrm{d}_{2}\right) / 2\right)$.

Isolates representing each morphotype that have caused necrosis on fruits were reisolated on PDA as described before. Then, they were compared with the original isolates $[19,26]$.

\section{Statistical analysis}

Data were analyzed using R software version 3.6.0 [31]. Data on quantitative characters (conidia length and width, ratio of conidia length/width and the average linear growth rate) between the surveyed districts were analyzed using an analysis of variance (ANOVA). The means of anthracnose lesion diameters on mangoes cv. Kent between the morphotype were also subjected to ANOVA test. When a significant effect was observed, Tukey post hoc test was used to separate means into homogeneous subsets at $5 \%$ level of significance.

Classification of Colletotrichum spp. isolates into morphotypes was obtained using a multivariate analysis performed on the morphological and cultural characteristics of the different isolates. A rectangular data matrix, with $\mathrm{n}$ rows corresponding to the identified isolates and eight columns corresponding to the variables used to characterize Colletotrichum isolates (table 1), was standardized by rows. The eight variables being qualitative (AAC, COC, CRC, CS and CES) and quantitative (CL, CWand ALGR), a Factor Analysis of Mixed Data (FAMD) was performed. Factor Analysis of Mixed Data allows analyzing the similarity between individuals by taking into account mixed variables: quantitative variables are subjected to a normalized Principal Component Analysis (PCA) and the qualitative variables to a multiple correspondence analysis (MCA) [32]. Quantitative and qualitative variables are normalized during the analysis to balance the influence of each group of variables. The FAMD was carried out with the FAMD function of the FactoMineR library, followed by an Agglomerative Hierarchical Clustering performed on the principal components of the FAMD using the HCPC function of the same library [33].

Quantitative data of Colletotrichum morphotypes obtained were compared using ANOVA one way and Tukey Post hoc test was used to compare the different groups. However, qualitative data of morphotypes were compared using Fisher's exact test at $5 \%$ significance.

The distribution map of Colletotrichum morphotypes across the seven districts surveyed was established using Diva-Gis version 7.5.0.

\section{RESULTS AND DISCUSSION}

\section{Isolation and identification of the causal agent}

Seventy colonies of Colletotrichum $\mathrm{sp}$. were isolated in the seven districts. Their number varied from district to district (table 2). The colour of most isolates was grey or grey whitish $(36 \%)$, followed by brownish grey $(11 \%)$, dark grey $(9 \%)$, whitish $(7 \%)$ and brown whitish (1\%). Three texture types were observed, cottony $(71 \%)$, abundant $(23 \%)$ 


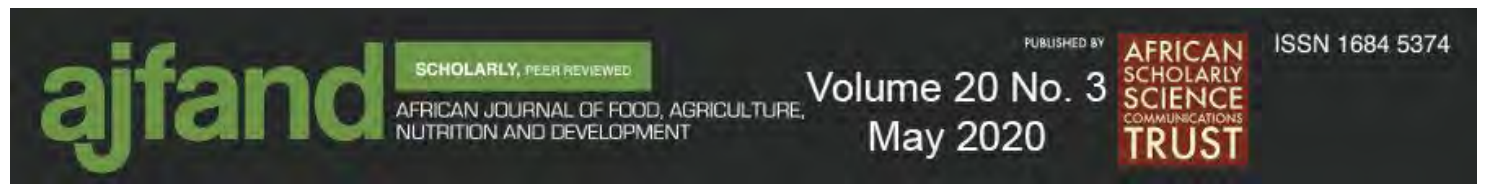

and closely appressed (6\%). Microscopic observation showed two different conidia shapes, cylindrical $(97 \%)$ and curved $(3 \%)$ corresponding to the two species of Colletotrichum recognized worldwide (figure 1). C. gloeosporioides which spores are cylindrical and $C$. acutatum species that possess conidia that are fusiform in shape [34].Three types of conidia end shape were distinguished, conidia rounded on both ends $(57 \%)$, one round and one sharp ended conidia (1\%) and both round and sharp ends in the same isolate $(42 \%)$. Conidia size varied significantly between isolates $(\mathrm{P}<0.001)$ and districts $(\mathrm{P}<0.001)$. Conidia length and width varied, respectively from 15.4 to $19.7 \mu \mathrm{m}$ and 4.8 to $5.8 \mu \mathrm{m}$. Isolates from Kabadougou district had the greatest mean of conidia length $(19.7 \mu \mathrm{m})$ followed by those from Hambol $(18.0 \mu \mathrm{m})$, Folon $(17.6 \mu \mathrm{m})$ and Tchologo $(17.5 \mu \mathrm{m})$, whereas mean conidia of isolates from Béré were shorter $(15.4 \mu \mathrm{m})$ (Table 4). The conidia size is conformed to those of previous studies[19,35]. The ratio of conidia length and width was significantly different between districts $(p<0.001)$ and varied from 3.02 to 3.73. Average Linear Growth Rate (ALGR) was significantly different between isolate $(p<0.01)$ and districts $(p<0.001) 7$ days after culture. Average Linear Growth Rate varied from 0.76 to $0.91 \mathrm{~cm} \mathrm{day}^{-1}$ (Table 2). Average Linear Growth Rate of isolates from Hambol district $\left(0.91 \mathrm{~cm} \mathrm{day}^{-1}\right)$ was greater than the others and the least rate was observed in Kabadougou district $\left(0.76 \mathrm{~cm} \mathrm{day}^{-1}\right)$.

Morphological characters (colony colour, conidia type and shape, conidia size and the average linear growth rate of isolate) varied significantly between isolates and districts. These differences could be due to variation, which might be attributed to the different environmental conditions in the different geographical areas where these isolates were identified. But also, on management or agronomic practices prevailing in these seven districts and on the life style of Colletotrichum species. Conidial morphology [24] and mycelial growth rate [36] have been reported to be a criterion that helps to differentiate the species of Colletotrichum for taxonomy purposes. However, they are not stable criterion of differentiation of Colletotrichum species, but play a significant role in variability within isolates [37].

C. acutatum was found only on mango leaves but not on fruits. This corroborated with findings of N'Guettia et al. [18] that demonstrated this species to be not implicated in post-harvest mango infection in Côte d'Ivoire. But it could be associated to field infection, particularly causing foliar spots, flowers, stems, immature fruits infection. However, C. gloeosporioides has been previously shown to be the causal agent of tropical fruit rots including mango, and this study also showed that most of the isolates identified from mango leaves and fruits belonged to the species complex $C$. gloeosporioides. This is in agreement with the study on the identification and characterization of Colletotrichum species associated with mango anthracnose in Guangxi, in China [38]. 

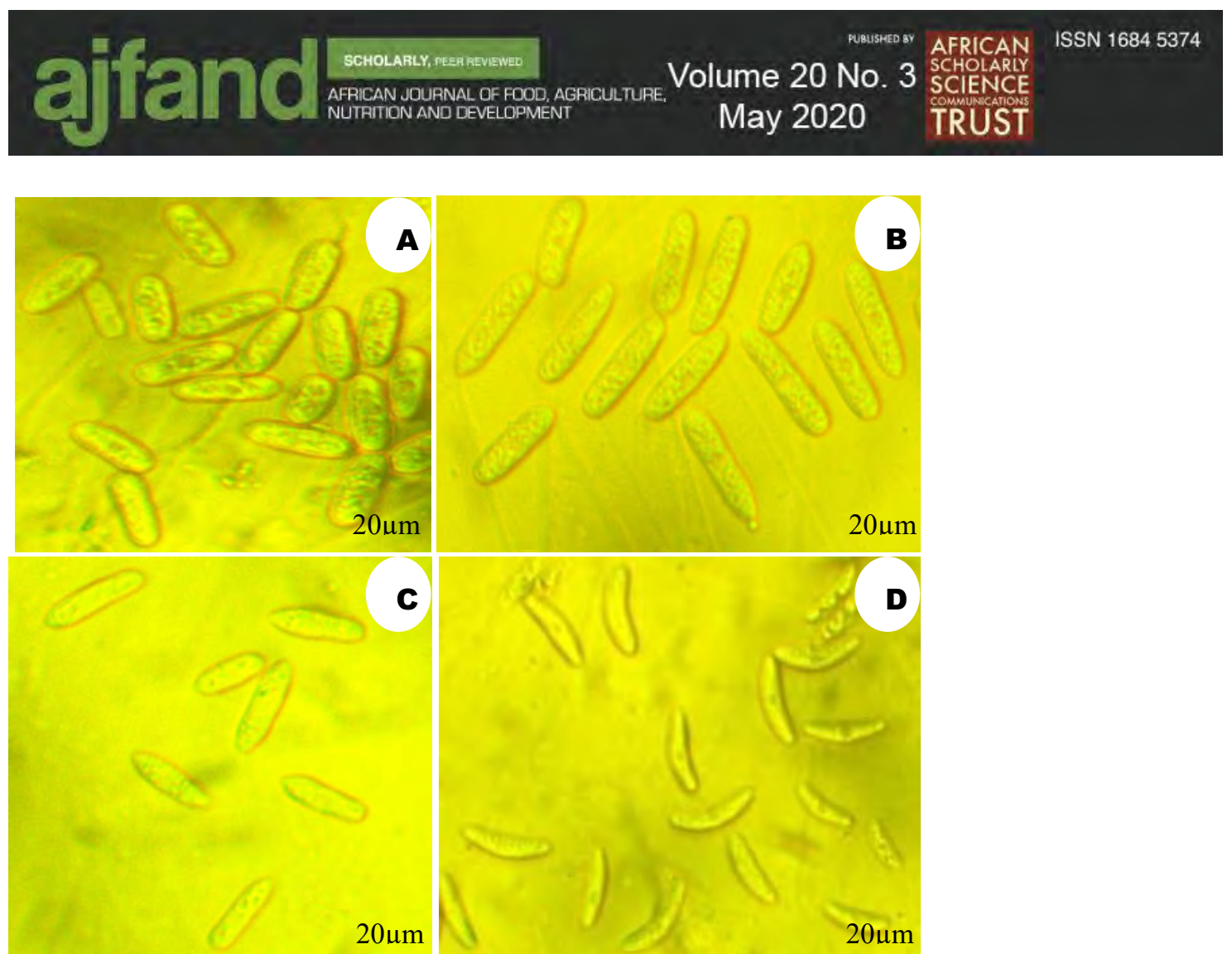

Figure 1: Conidia shape of the different Colletotrichum species isolates

Conidia of Colletotrichum gloeosporioides rounded on both ends (A), both round and sharp ends in the same isolate (B), one round and one sharp ended conidia (C) and fusiform conidia of Colletotrichum acutatum (D) GX400

\section{Classification of Colletotrichum sp. isolates}

Factor Analysis of Mixed Data analysis showed that 50\% of the variation in data was explained by the first 6 principal axes or components. The first and second components accounted, respectively for $11.7 \%$ and $9.7 \%$ of the total variation. Characters contributing most heavily on the first component were conidia length and width. Those contributing to the second component were reverse and obverse colour of colonies and conidia ends shape. The hierarchical clustering performed using the eight characters suggested four clusters or morphotypes (figure 2 ). The four clusters ( 1 to 4 ) contained, respectively $5(7 \%), 7(10 \%), 17(24 \%)$ and $41(59 \%)$ isolates. Isolates of morphotype 1 were characterized by whitish obverse and reverse colour with an abundant mycelia aerial aspect. The second morphotype were represented by isolates with obverse and reverse brownish grey colour and contained both conidia with two rounded ends, and one rounded and one sharped end. The third morphotype consisted of isolates with obverse and reverse grey whitish colour. The fourth morphotype consisted of isolates with obverse and reverse respectively dark grey and grey or vice versa (figure 3). Conidia length and width of morphotypes varied respectively from 14.5 to $17.5 \mu \mathrm{m}$ and 4.6 to 5.2 $\mu \mathrm{m}$. Average Linear Growth Rate varied from 0.84 to $0.87 \mathrm{~cm}$. However, no significant differences were observed between the four morphotypes for these variables (Table 3 ). Three of the five qualitative variables were used to characterize the four morphotypes according to Fisher exact test. Colletotrichum isolates obverse $(\mathrm{P}<0.001)$ and reverse colour $(\mathrm{P}<0.001)$, and their conidia ends $(\mathrm{P}<0.01)$ varied significantly between morphotypes. The isolates mycelia aerial aspect $(\mathrm{P}>0.05)$ and conidia shape $(\mathrm{P}>0.05)$ were not significantly different. However, conidial morphology could not be confidently 


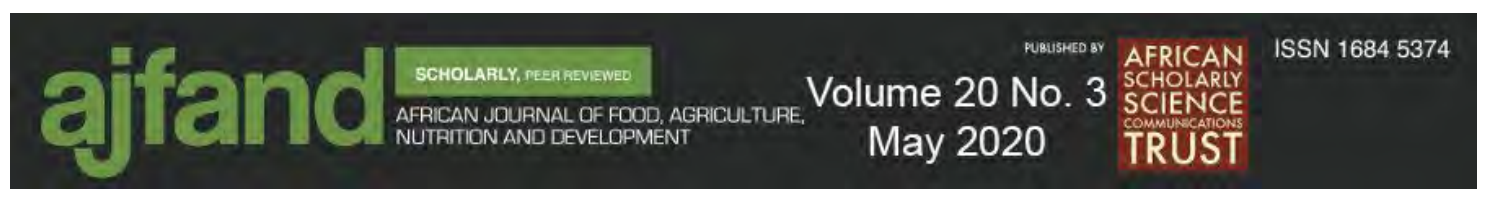

used alone to determine species within Colletotrichum complex [10]. Mycelial growth rate do not also present a decisive taxonomic value in the differentiation of Colletotrichum species, but may play an important role in intraspecific variability [37]. Characters which proved to be discriminatory in this study were isolates obverse and reverse colour, and conidia ends shape according to Fisher's exact test. This disagrees with Baxter et al. [24] who found that discriminatory characters were: presence or absence of setae; conidia shape and size, and whether conidia are produced mainly from condiomata or from hyphal side branches; presence or absence of perithecia; and texture and colour of marginal zones in culture. Lesser contributing factors were: appressorium shape and width; presence or absence of sclerotia and conidiomata; colony growth rate; and the colour of the colony reverse, central zone. No grouping of isolates by mango organ (leaves or fruits), seasons (rainy and dry) or districts were found in this study. Thus, there is no spatial or temporal distribution of Colletotrichum isolates infecting mango in the north of Côte d'Ivoire. 

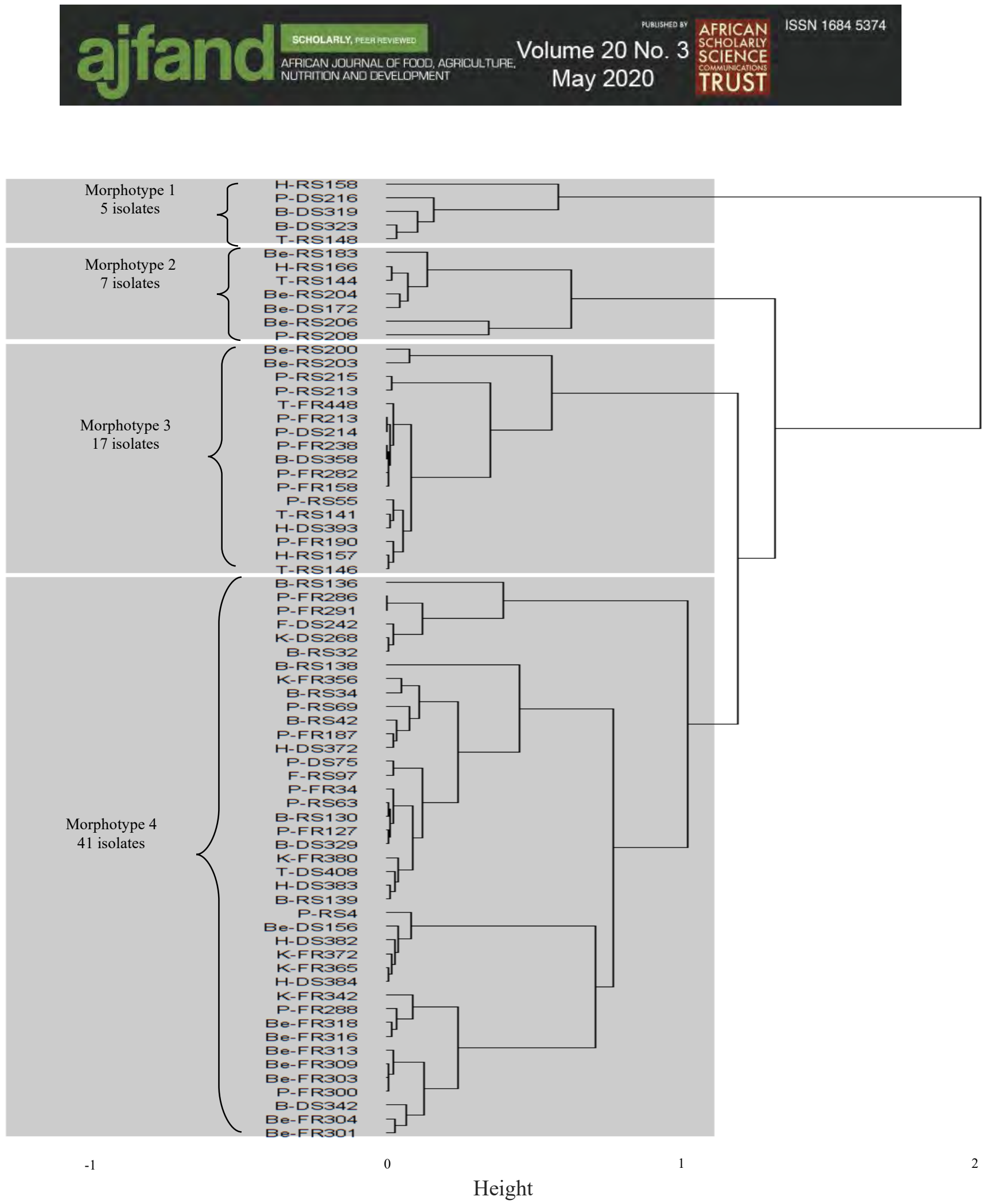

Figure 2: Dendrogram resulting from the hierarchical cluster analysis showing the four morphotypes according to the eight variables used for multivariate analysis

Isolates names: First letter are district names (B: Bagoue, Be: Bere, F: Folon, H: Hambol, $\mathrm{K}$ : Kabadougou, P: Poro and T: Tchologo); RS and DS: isolates from leaves respectively in rainy and dry seasons and Fr: isolates from fruits 

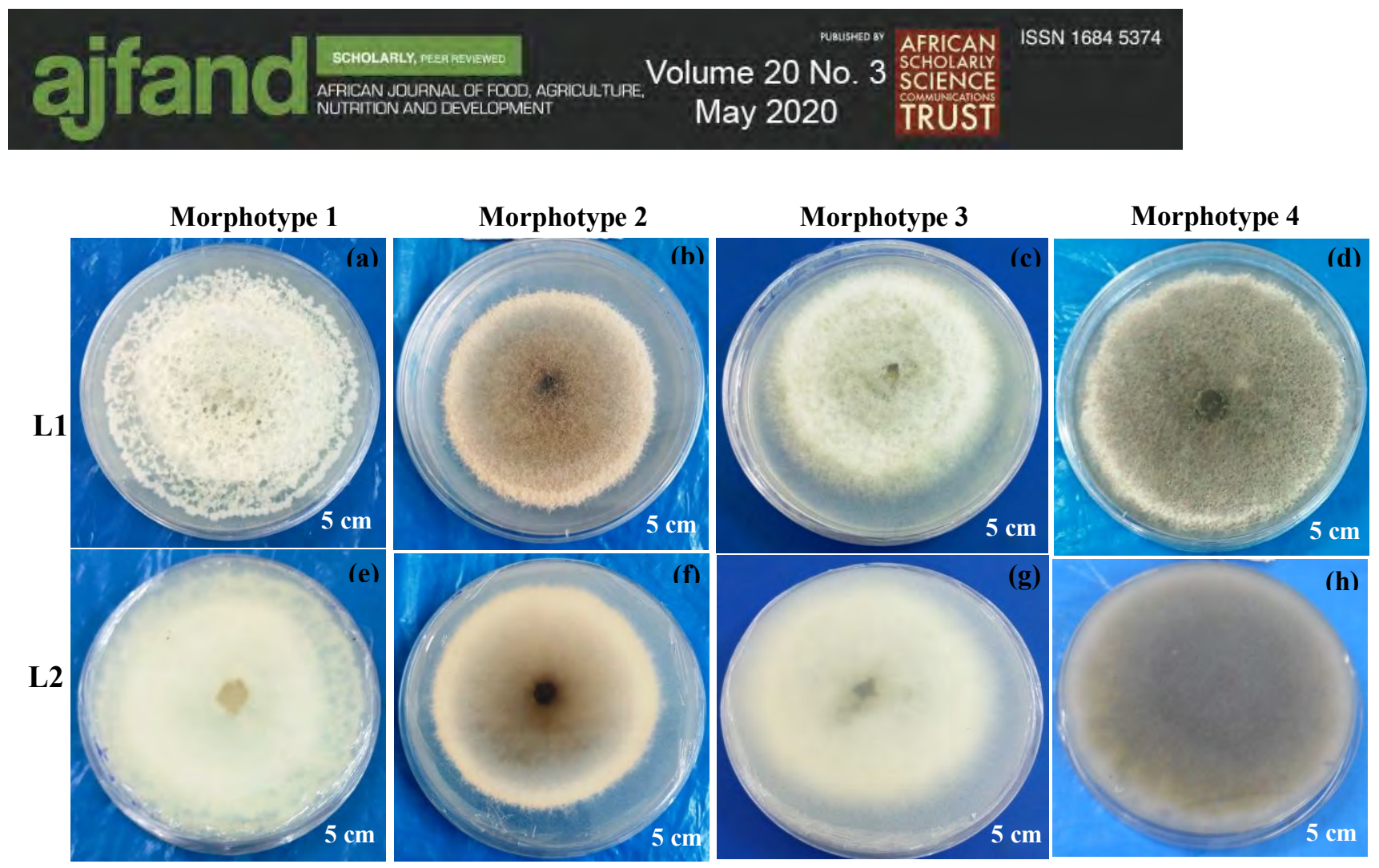

Figure 3: Four morphotypes of Colletotrichum species isolates identified from leaves and fruits L1 and L2 obverse and reverse views of the mycelium. Morphotype 1: whitish obverse (a) and reverse (e) mycelial colour; Morphotype 2: obverse (b) and reverse brownish grey (f) colour; Morphotype 3: obverse (c) and reverse grey whitish colour (g); Morphotype 4: obverse (d) and reverse dark grey (h) or vice versa

\section{Pathogenicity tests}

Four isolates corresponding to each morphotype inoculated on green mature fruits showed anthracnose symptom typically similar to those observed on fruits after postharvest storage. Five days after inoculation, mean lesions size produced differed significantly $(\mathrm{P}<0.001)$ between morphotypes. Higher lesion size was produced by isolate of morphotype $4(7.6 \mathrm{~mm})$ and the smallest by morphotype $2(1.7 \mathrm{~mm})$. Two groups of isolates were formed after Tukey post hoc test. Isolates of morphotypes 1 and 4 were more pathogenic than the others with respectively 5.4 and $7.6 \mathrm{~mm}$ and different to the control. Isolates of morphotype 2 and 3 were less pathogenic than those of morphotype 1 and 4 (table 4). Lesion size of morphotypes (1 and 4) belong to the category $1(5-9 \mathrm{~mm})$ of lesion rating scale [29]. However, the mean lesion size produced was smaller than those obtained by Sanders \& Korsten [30] and N'Guettia et al. [19] on mango. They obtained respectively $29.44 \mathrm{~mm}$ and 10 to $21.3 \mathrm{~mm}$ lesion five days after inoculation. Thus, their isolates were more pathogenic than those used in this study.

\section{Distribution of Colletotrichum sp. morphotypes}

Colletotrichum morphotypes were unequally distributed across the seven districts (Figure 4). Morphotype 4 was observed in the seven districts surveyed. This morphotype was the most virulent in pathogenity test. Most of Colletotrichum sp. isolates belong to this morphotype (59\%). Four morphotypes ( 1 to 4 ) were found in three districts (Hambol, Poro and Tchologo). Three morphotyphes (1, 3 and 4) were found in two districts (Bagoué and Béré). However, one morphotype were found in two districts (Folon and Kabadougou) located in the north-west of Côte d'Ivoire. Mango orchards in some districts were susceptible to some isolates of morphotype. Therefore, there is a spatial 


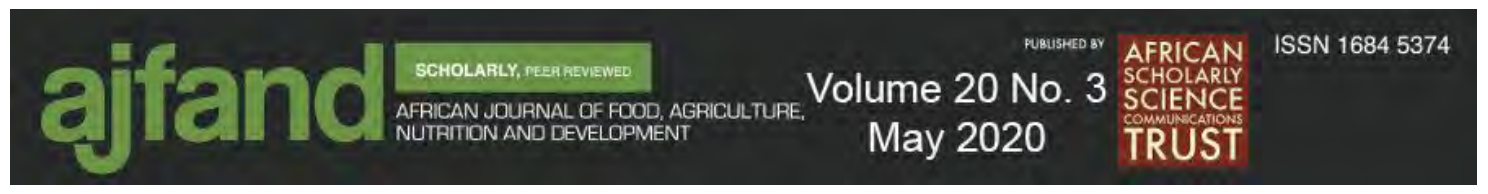

distribution of Colletotrichum morphotype infecting mango orchards in the north of Côte d'Ivoire. This could be attributed to environmental factors but also on agronomic practices prevailing in these districts. Differences observed between morphotypes could possibly be ascribed to adaptation of the pathogen to a less susceptible host, thereby becoming more virulent to overcome the host's defense mechanisms [39]. Because, isolates of morphotype 4, which caused the greatest lesion after inoculation was represented in the seven districts. 

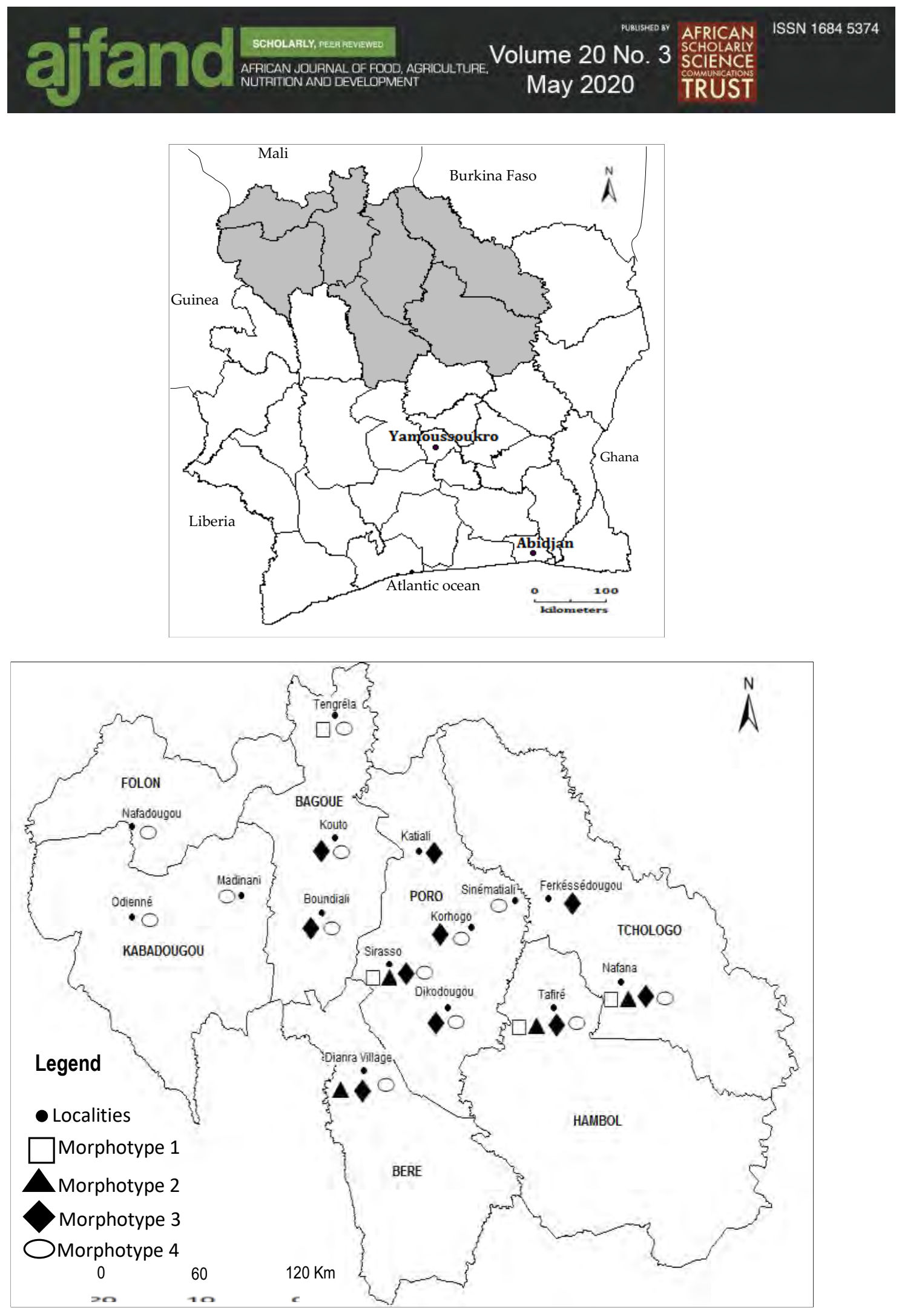

Figure 4: Distribution of Colletotrichum species isolates morphotypes in the north of Côte d'Ivoire 


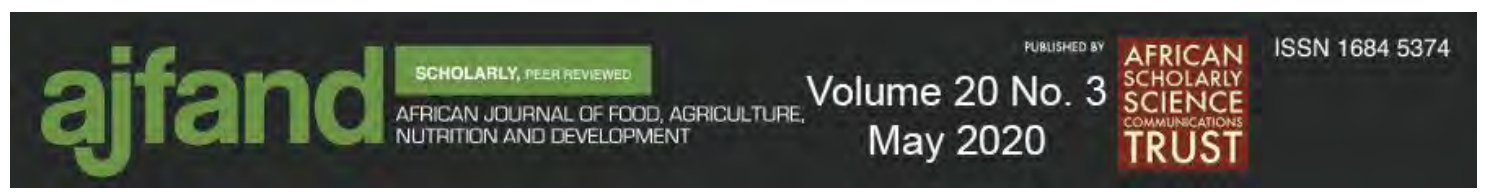

\section{CONCLUSION}

The present study highlighted that morphological variation of Colletotrichum species existed among the different isolates and the districts surveyed. Based on multivariate analysis on morphological features, the seventy isolates of Colletotrichum species were grouped into 4 morphotypes. These morphotypes were characterized by qualitative characters such as conidia ends shape, colony obverse and reverse colour. Quantitative variables contributed lesser than qualitative ones in this differentiation. Identification of Colletotrichum species based on these characters is difficult because of their enormous variation. But, also Colletotrichum, is a complex of species comprising morphologically indistinguishable but genetically and biologically isolated species. Thus, to overcome the inadequacies of this traditional morphological identification, sequence analyses are still to be carried out to confirm the identity of these Colletotrichum species isolates. Because, for understanding the epidemiology of anthracnose, a precise determination of the etiology of the different causal agent is essential and is of paramount importance to investigate whether the same or different pathogens are associated with this disease in Côte d'Ivoire.

\section{ACKNOWLEDGEMENTS}

The authors are grateful to the Fondation Louis Omer DECUGIS and the Sociéte Internationale d'Importation (SIIM) for funding this research. They would also like to thank the Societé de Diverses Prestations et d'Exportations (Sodipex SARL) for their technical support. 


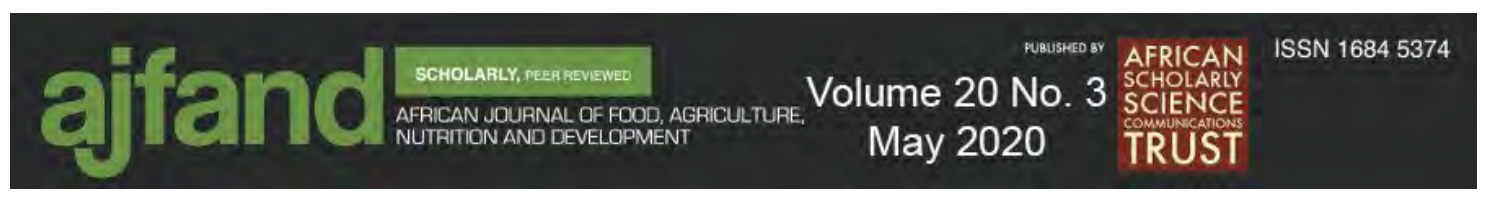

Table 1: Quantitative and qualitative characters used to describe and classify Colletotrichum sp. isolates

\begin{tabular}{|l|l|l|}
\hline Variables & Definition & Modalities or unit \\
\hline 1- AAC & Aerial aspect of colonies & Abundant, cottony, closely appressed \\
\hline 2- COC & Colony obverse colour & $\begin{array}{l}\text { whitish, grey, grey whitish, brown whitish, brownish grey } \\
\text { and dark grey }\end{array}$ \\
\hline 3- CRC & Colony reverse colour & $\begin{array}{l}\text { whitish, grey, grey whitish, brown whitish, brownish } \\
\text { grey, brownish dark, dark grey and black }\end{array}$ \\
\hline 4- CS & Conidia shape & Cylindrical, curved \\
\hline 5- CES & Conidia extremity shape & $\begin{array}{l}\text { Conidia rounded on both ends; 1 round and 1 sharp ended } \\
\text { conidia; } 2 \text { both ends sharpened conidia; Conidia rounded } \\
\text { on both ends; and 1 round and 1 sharp ended conidia }\end{array}$ \\
\hline 6- CL & Conidia length & $\mu \mathrm{m}$ \\
\hline 7- CW & Conidia width & $\mu \mathrm{m}$ \\
\hline 8- ALGR & Average linear growth rate & $\mathrm{cm} \mathrm{day}$ \\
\hline
\end{tabular}

* Average linear growth rate in centimeter per day

Table 2: Quantitative characters (mean $\pm \mathrm{SD}^{*}$ ) across the surveyed districts

\begin{tabular}{|l|c|c|c|c|c|}
\hline Districts & $\begin{array}{c}\text { Number of } \\
\text { isolates }\end{array}$ & $\begin{array}{c}\text { Conidia length } \\
(\mu \mathrm{m})^{\mathrm{a}}\end{array}$ & $\begin{array}{c}\text { Conidia width } \\
(\mu \mathrm{m})^{\mathrm{a}}\end{array}$ & $\begin{array}{c}\text { Ratio } \\
(\text { Length/width })\end{array}$ & $\begin{array}{c}\text { Average linear growth } \\
\text { rate }\left(\mathrm{cm} \mathrm{day}^{-1}\right)^{\mathrm{a}}\end{array}$ \\
\hline Kabadougou & 6 & $19.7 \pm 4.0 \mathrm{a}$ & $5.2 \pm 0.6 \mathrm{~cd}$ & $3.73 \pm 0.4 \mathrm{a}$ & $0.76 \pm 0.1 \mathrm{~b}$ \\
\hline Hambol & 8 & $18.0 \pm 1.2 \mathrm{~b}$ & $5.4 \pm 0.3 \mathrm{~b}$ & $3.32 \pm 0.3 \mathrm{~b}$ & $0.91 \pm 0.1 \mathrm{a}$ \\
\hline Folon & 2 & $17.6 \pm 1.7 \mathrm{bc}$ & $5.8 \pm 0.1 \mathrm{a}$ & $3.02 \pm 0.3 \mathrm{bc}$ & $0.88 \pm 0.2 \mathrm{ab}$ \\
\hline Tchologo & 6 & $17.5 \pm 0.9 \mathrm{bc}$ & $5.4 \pm 0.3 \mathrm{~b}$ & $3.27 \pm 0.3 \mathrm{bc}$ & $0.85 \pm 0.1 \mathrm{ab}$ \\
\hline Bagoue & 12 & $17.2 \pm 3.1 \mathrm{bc}$ & $5.2 \pm 0.7 \mathrm{~cd}$ & $3.30 \pm 0.3 \mathrm{bc}$ & $0.90 \pm 0.1 \mathrm{a}$ \\
\hline Poro & 22 & $16.2 \pm 2.9 \mathrm{c}$ & $5.0 \pm 0.7 \mathrm{~d}$ & $3.22 \pm 0.4 \mathrm{bc}$ & $0.83 \pm 0.1 \mathrm{ab}$ \\
\hline Bere & 14 & $15.4 \pm 3.7 \mathrm{~d}$ & $4.8 \pm 0.7 \mathrm{e}$ & $3.18 \pm 0.6 \mathrm{c}$ & $0.83 \pm 0.1 \mathrm{ab}$ \\
\hline
\end{tabular}

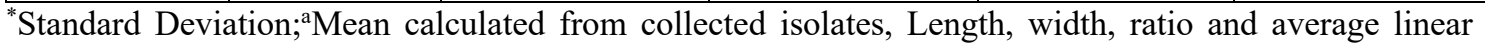
growth rate with the same letter are not significantly different according to Tukey's test at $\mathrm{P}<0.05 \%$

Table 3: Quantitative variables (mean \pm SD) of the four morphotypes obtained after the clustering ${ }^{\mathbf{a}}$

\begin{tabular}{|c|c|c|c|c|}
\hline Morphotypes & $\begin{array}{c}\text { Number } \\
\text { of } \\
\text { isolates }\end{array}$ & Conidia length $(\mu \mathrm{m})$ & Conidia width $(\mu \mathrm{m})$ & Average linear growth rate $\left(\mathrm{cm} \mathrm{day}^{-1}\right)$ \\
\hline 1 & 5 & $14.5 \pm 4.1$ & $4.6 \pm 1.0$ & $0.86 \pm 0.1$ \\
\hline 2 & 7 & $17.5 \pm 3.4$ & $5.1 \pm 0.7$ & $0.87 \pm 0.1$ \\
\hline 3 & 17 & $16.6 \pm 2.7$ & $5.2 \pm 0.4$ & $0.87 \pm 0.1$ \\
\hline 4 & 41 & $17.2 \pm 3.0$ & $5.2 \pm 0.7$ & $0.84 \pm 0.0$ \\
\hline
\end{tabular}

${ }^{a}$ Mean calculated from collected isolates of the four morphotypes: conidia length and width, ratio and average linear growth rate with are not significantly different according to Analysis of Variance 


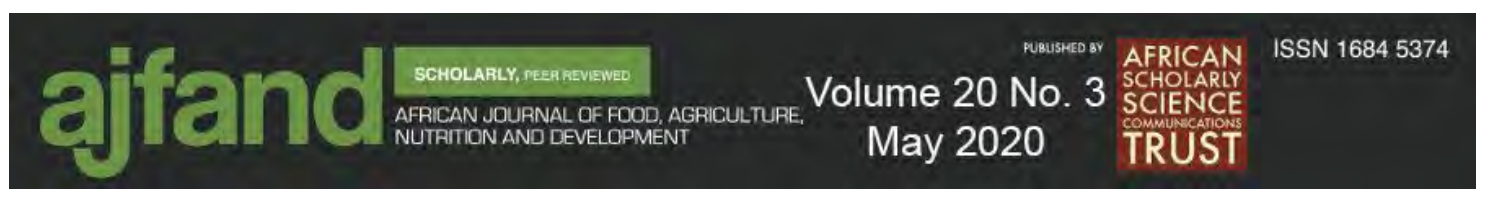

Table 4: Lesions size (mean $\pm \mathrm{SD}, \mathbf{m m})$ five days after inoculation test ${ }^{\mathrm{a}}$

\begin{tabular}{|c|c|}
\hline Morphotypes & Lesions size $(\mathrm{mm})$ \\
\hline 1 & $5.4 \pm 3.6 \mathrm{a}$ \\
\hline 2 & $1.7 \pm 0.3 \mathrm{~b}$ \\
\hline 3 & $2.4 \pm 0.7 \mathrm{~b}$ \\
\hline 4 & $7.6 \pm 3.0 \mathrm{a}$ \\
\hline Control & $0.0 \pm 0.0 \mathrm{c}$ \\
\hline
\end{tabular}

${ }^{a}$ Mean of lesion size with the same letter are not significantly different according to Tukey's test at $\mathrm{P}<0.05 \%$ 


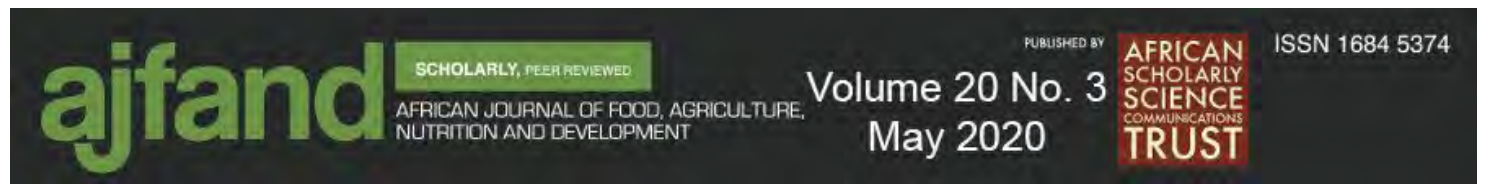

\section{REFERENCES}

1. Bailey JA and MJ Jeger Colletotrichum: Biology, Pathology and Control, CAB International, Wallingford, UK; 1992: 4009-4013.

2. Johnston PR and D Jones Relationships among Colletotrichum isolates from fruit-rots assessed using rDNA sequences. Mycologia: 1997;89:420-430.

3. Ploetz RE and O Prakash Foliar, Floral, and Soil Borne Diseases. In: Litz R (eds). Mango Botanic Production and Uses, Oxon, UK: CAB International; 1997: 281-225.

4. Sangeetha CG and RD Rawal Temperature requirement of different isolates of Colletotrichum gloeosporioides isolated from mango. Am. J. Sci. Res. 2009;4:2025.

5. Chowdhury MNA, Rahim MA, Khalequzzaman KM, Alam MJ and MR Humauan Effect of horticultural practices on incidence of anthracnose on yield and quality of mango. Int. J. Sustain. Crop. Prod. 2008;3:1-9.

6. Arauz LF Mango anthracnose: Economic impact and current options for integrated management. Plant. Dis. 2000;84:600-611.

doi:10.1094/PDIS.2000.84.6.600

7. Chowdhury MNA and MA Rahim Integrated crop management to control anthracnose (Colletotrichum gloeosporioides) of mango. J. Agric. Rural. Dev. 2009;7:115-120. doi:10.3329/jard.v7i1.4430

8. Akem CN Mango anthracnose disease: present status and future research priorities. Plant Pathol. J. 2006;5:266-273. doi:10.3923/ppj.2006.266.273

9. Ploetz RC, Benscher D, Vázquez A, Colls A, Nagel J and B Schaffer Mango Decline: Research in Florida on an apparently wide-spread disease complex. Vth Int. Mango Symp. 1996; 547-557.

10. Phoulivong S, Cai L, Chen H, McKenzie EHC, Abdelsalam K, Chukeatirote E and KD Hyde Colletotrichum gloeosporioides is not a common pathogen on tropical fruits. Fungal Divers. 2010;44:33-43.

11. Hyde KD, Cai L, Cannon PF, Crouch JA, Crous PW, Damm U, Goodwin PH, Chen H, Johnston PR, Jones EBG, Liu ZY, McKenzie EHC, Moriwaki J, Noireung P, Pennycook SR, Pfenning LH, Prihastuti H, Sato T, Shivas RG, Tan YP, Taylor PWJ, Weir BS, Yang YL and JZ Zhang Colletotrichum names in current use. Fungal Divers. 2009;39:147-182. 


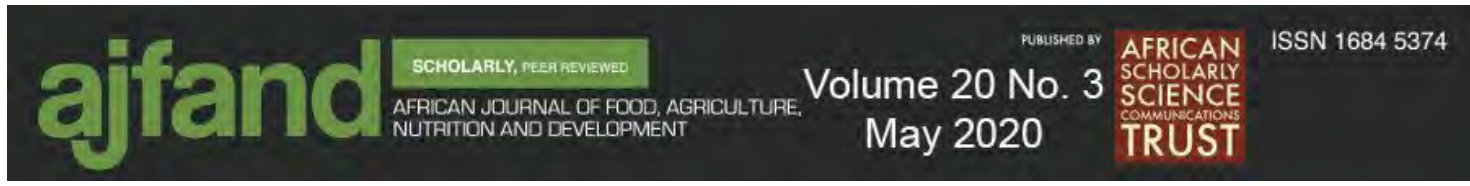

12. Johnston $\mathbf{P}$ Are stable, consistent, reliable, and useful species names possible within Colletotrichum? Colletotrichum Dis. Fruit Crop. Summ. Invit. Pap. Precongress Work. ICPP 10, Torino, Italy, 2008;1-7.

13. Cai L, Hyde KD, Taylor PWJ, Weir BS, Waller J, Abang MM, Zhang JZ, Yang YL, Phoulivong S, Liu ZY, Prihastuti H, Shivas RG, McKenzie EHC and PR Johnston A polyphasic approach for studying Colletotrichum. Fungal Divers. 2009;39:183-204.

14. Gunnell PS and WD Gubler Taxonomy and morphology of Colletotrichum species pathogenic to strawberry. Mycologia 1992;84:157-165. doi: $10.2307 / 3760246$

15. Smith BJ and LL Black Morphological, cultural and pathogenic variation among Colletotrichum species isolated from strawberry. Plant Dis 1990;74:69-76.

16. Sutton BC The genus Glomerella and its anamorph Colletotrichum. In: J. A. Bailey and M. J. Jeger (eds). Colletotrichum Biol. Pathol. Control, Wallingford, UK: 1992,1-26.

17. Kouamé KG, Abo K, Dick E, Bomisso EL, Kone D and SAké Artificial wounds implication for the development of mango (Mangifera indica L. anacardiaceae) fruit disease caused by Colletotrichum gloeosporiö̈des (Penz.) Sacc. (Glomerellaceae). Int. J. Biol. Chem. Sci. 2010;4:1621-1628. doi:10.4314/ijbcs.v4i5.65579

18. N'Guettia MYN, Kouassi N, Diallo HA and FRYY Kouakou Evaluation of Anthracnose Disease of Mango (Mangifera indica L.) Fruits and Characterization of Causal Agent in Côte d'Ivoire. Int. J. Agric.Innov. Res. 2014;2:1008-1017.

19. N'Guettia YM, Diallo AH, Kouassi N and F Coulibaly Diversité morphologique et pathogénique des souches de Colletotrichum sp. responsables de l'anthracnose de la mangue en Côte d'Ivoire. J. Anim. Plant. Sci. 2013;18:2775-2784.

20. Onyeani CA, Osunlaja SO, Owuru OO and OS Sosanya Mango fruit anthracnose and the effects on mango yield and market values in Southwestern Nigeria. Asian J. Agric. Res.2012;6:171-179. doi:10.3923/ajar.2012.171.179

21. Okigbo RN and MI Osuinde Fungal Leaf Spot Diseases of Mango (Mangiferaindica L) in Southeastern Nigeria and Biological Control with Bacillus subtilis. Plant Prot. Sci. 2003;39:70-77. doi:https://doi.org/10.17221/3829-PPS

22. Kouamé G. K, Sorho F, Koné D, Bomisso LE, Aké S and J Yatty Activité pathologique comparée de deux isolats de Colletotrichum gloeosporioïdes (PENZ.) sur deux varietés de mangues (Mangifera indica L). Agron. Afric. 2011;23:33-41. 


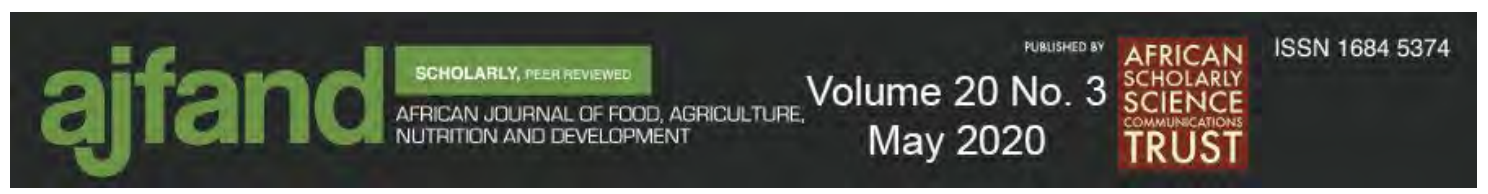

23. Diedhiou PM, Dramé NMA and PI Samb Alteration of post harvest diseases of mango Mangifera indica through production practices and climatic factors. African J. Biotechnol. 2007;9:1087-1094. doi:https://doi.org/10.5897/AJB2007.000-2140

24. Baxter AP, Eicker A and NJ Dippenaar Multivariate analysis of some characteristics of South African isolates of Colletotrichum. South African J. Bot. 1993;59:557-565. doi:10.1016/S0254-6299(16)30670-6

25 Jahan N, Sultana S, Adhikary SK, Rahman S and S Yasmin Evaluation of the growth performance of Trichoderma harzianum (Rifai.) on different culture media. IOSR J. Agric. Vet. Sci. 2013;3:44-50. doi:10.9790/2380-0344450

26. Tucho A, Lemessa $\mathbf{F}$ and $\mathbf{G}$ Berecha Distribution and occurrence of mango anthracnose (Colletotrichum gloesporioides). Plant Pathol. J. 2014;13:268-277. doi:10.3923/ppj.2014.268.277

27. Lin Q, Kanchana-udomkarn C, Jaunet $\mathbf{T}$ and $\mathbf{O}$ Mongkolporn Genetic analysis of resistance to pepper anthracnose caused by Colletotrichum capsici. Thai J. Agric. Sci. 2002;35:259-264.

28. Than PP, Prihastuti H, Phoulivong S, Taylor PW and KD Hyde Chilli anthracnose disease caused by Colletotrichum species. J. Zhejiang Univ. Sci. B 2008;9:764-778. doi:10.1631/jzus.B0860007

29 Sanders GM and L Korsten Comparison of cross inoculation potential of of South African avocado and mango isolates of Colletotrichum gloeosporioides. Microbiol. Res.2003;158:143-150. doi:10.1139/b03-073

30 Sanders GM and L Korsten A comparative morphological study of South African avocado and mango isolates of Colletotrichum gloeosporioides. Can. J. Bot. 2003;81:877-885. doi:10.1139/b03-073

31. R Core Team R A Language and Environment for Statistical Computing. R Foundation for Statistical Computing, Vienna, Austria, URL https://www.Rproject.org/2019

32. Pagès J Analyse factorielle de données mixtes. Rev. Stat. Appliquée. 2004;52:93111.

33. Husson F, Lê $\mathbf{S}$ and $\mathbf{J}$ Pages Exploratory Multivariate analysis by example using R. J Stat. Softw.2011;40:1381-1385.

34. Peres NA, Kuramae EE, Dias MS and NL De Souza Identification and characterization of Colletotrichum spp. affecting fruit after harvest in Brazil. $J$. Phytopathol. 2002;150:128-134. doi:10.1046/j.1439-0434.2002.00732.x 


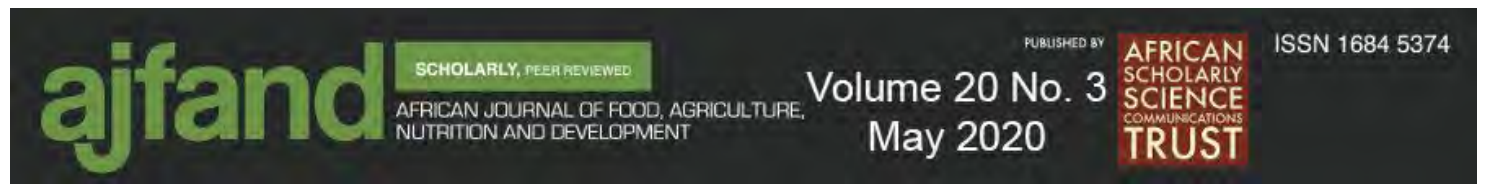

35. Ajay Kumar G Colletotrichum gloeosporioides: Biology, Pathogenicity and Management in India. J. Plant Physiol. Pathol. 2014;2:2. doi:10.4172/2329955X.1000125

36. Liu B, Louws FJ, Sutton TB and JC Correll A rapid qualitative molecular method for the identification of Colletotrichum acutatum and C. gloeosporioides. Eur. J. Plant Pathol. 2012;132:593-607. doi:https://doi.org/10.1007/s10658-0119904-1

37. Serra IMR de S, Menezes M, Coelho RSB, Ferraz GMG, Montarroyos AVV and LSS Martins Morphophysiological and molecular analysis in the differentiation of Colletotrichum gloeosporioides isolates from the cashew and mango trees. Brazilian Arch. Biol. Technol. 2011;54:1099-1108. doi:10.1590/S1516-89132011000600004

38. Mo J, Zhao G, Li Q, Solangi GS, Tang L, Guo T, Huang, S and T Hsiang Identification and Characterization of Colletotrichum Species Associated with Mango Anthracnose in Guangxi, China. Plant Dis. 2018;102:1283-1289. doi:10.1094/pdis-09-17-1516-re

39. Alahakoon PW, Brown, AE and and S Sreenivasaprasad Cross-infection potential of genetic groups of Colletotrichum gloeosporioides on tropical fruits. Physiol. Mol. Plant Pathol. 1994;44:93-103. doi:https://doi.org/10.1016/S08855765(05)80104-3 